\title{
Assessment of Corrosion Damage in a Finger-Type Slug Catcher
}

\author{
V. C. Nettikaden • D. Ifezue $\cdot$ F. H. Tobins
}

Submitted: 24 September 2013/Published online: 23 October 2013

(C) The Author(s) 2013. This article is published with open access at Springerlink.com

\begin{abstract}
Corrosion pits of up to $6 \mathrm{~mm}$ depth, associated with areas of high solid deposition were discovered in the finger-type slug catcher and glycol sump during routine inspection (first in 2005 and then in 2013) following lengthy periods of below-threshold CI injection and partial implementation of the corrosion management plan. Corrosion rates were predicted to have increased from $0.46 \mathrm{~mm} / \mathrm{year}$ in 2005 to $0.71 \mathrm{~mm} /$ year in 2007 and then decreased to $0.41 \mathrm{~mm} /$ year in 2008. Subsequent integrity assessments concluded that the slug catcher was not fit for continued operation at the current rate of pitting and was therefore shut down to prevent potential loss of containment. Results of API 579 fitness for service assessments of the corroded areas justified the subsequent decision to de-rate the system and that no further corrosion can be tolerated at the original design pressure, at least until the rates of corrosion and its mechanisms were fully understood. Based on the damage morphology, chemical and monitoring data and theoretical concepts, a synergy of mechanisms (under deposit corrosion, $\mathrm{CO}_{2}$ corrosion, preferential weld corrosion and microbial-induced corrosion) is identified as being responsible for the observed damage. The short-term mitigation plan is to routinely inspect the damaged locations (by UT wall thickness checks) while simultaneously implementing a corrosion management and control plan which consists of:
\end{abstract}

\section{C. Nettikaden}

Manchester, UK

D. Ifezue $(\square)$

2 Gibsmere Close, Timperley, Altrincham WA15 7LL, UK

e-mail: difezue@msn.com

F. H. Tobins

Department of Mechanical Engineering, University of Abuja, P.M.B 117, Abuja, Nigeria continuous inhibitor dosing, $\mathrm{pH}$ stabilisation (with MEA/ DEA) to above $\mathrm{pH}$ 6, batch biociding, sampling of residuals, chlorides, iron, SRB/GHB count, water cut, water content and $\mathrm{pH}$ of lean glycol, glycol content of pipeline fluid and online monitoring. The inspection, sampling and monitoring results should then be reviewed initially monthly, subsequently quarterly by the corrosion and integrity team in order to assess the rate of pitting. If the target $(<0.125 \mathrm{~mm} /$ year) is being breached frequently, then alternative but more costly mitigation should be considered such as repair or outright replacement of the finger-type by vessel-type slug catchers which have built-in sand jetting systems designed to deal with high deposition rates and are therefore considered less prone to associated corrosion damage.

Keywords Bacterial corrosion .

Corrosion failure analysis · Deposits · Heat-affected zone · Pitting $\cdot$ Weld $\cdot$ Failure mechanism

\section{Introduction}

\section{Background}

Finger-type slug catcher has been in operation for 17 years and was designed to receive dehydrated gas and condensate from offshore platforms. When operated to design, the inhibited corrosion rate should be less than $0.1 \mathrm{~mm} /$ year. However, for a 5-year period, the slug catcher received wet gas due to process upsets at the platform resulting in the condensate and gas streams being contaminated with produced water. During this period spheres were ran with inhibited MEG to remove liquids and hence prevent hydrate formation. Routine inspection revealed the presence of severe corrosion pits in the lower sections of the slug 
Fig. 1 Process flow diagram of a slug catcher

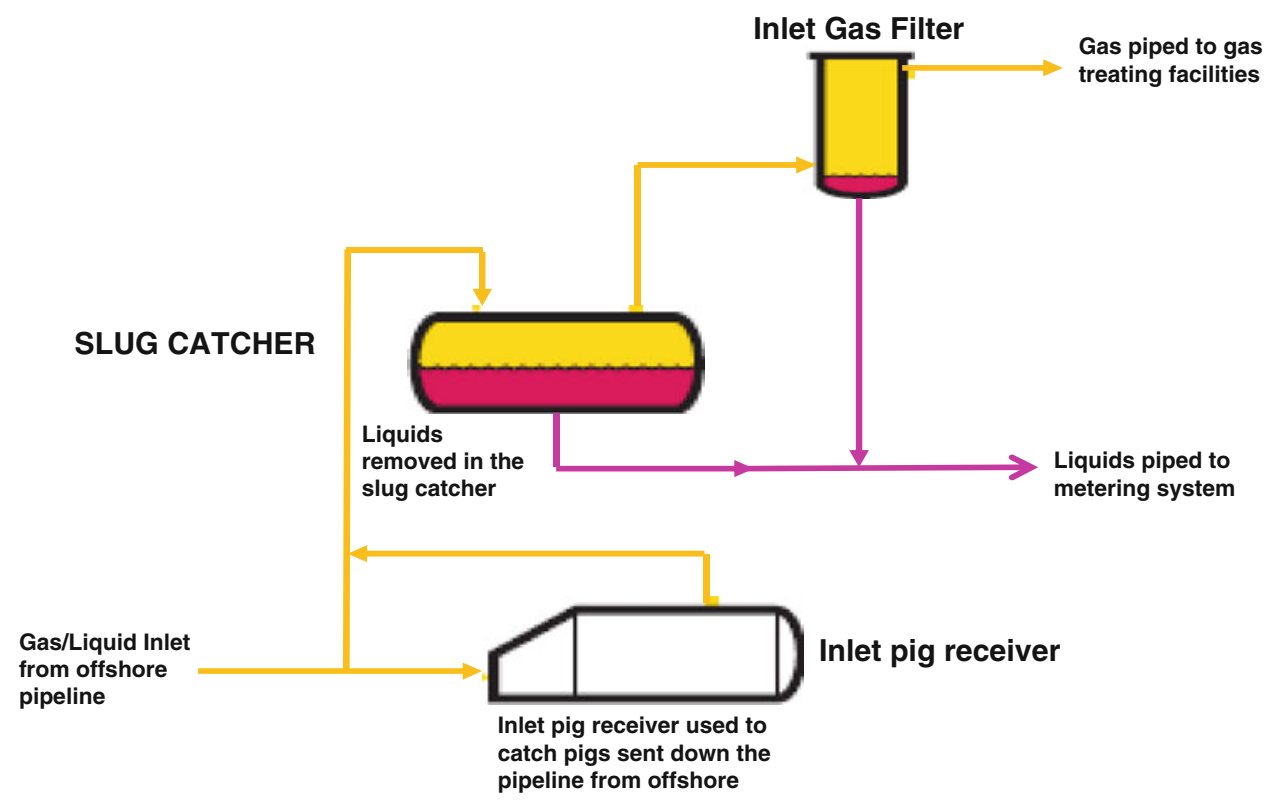

catcher fingers corresponding to the areas of heavy solid deposition and also in the glycol sump. Subsequent integrity assessments concluded that the slug catcher was not fit for continued operation at the current rate of pitting and was therefore shut down to prevent potential loss of containment. Results of API579 [1] fitness for service assessments of the corroded areas justified the subsequent decision to derate the system and that no further corrosion can be tolerated at the original design pressure, at least until the rates of corrosion and its mechanisms are fully understood. The estimated capital cost of this failure (discounting lost production) range from approx. $£ 300 \mathrm{~K}-£ 1.2 \mathrm{~m}$ for a repair options to $>£ 4 \mathrm{~m}$ for replacement options. This paper assesses the main damage mechanisms and recommends an inspection and corrosion control plan to reduce the current corrosion rate from 0.46 to $0.1 \mathrm{~mm} /$ year and hence extend operating life for another 20 years.

\section{Process Description}

Finger-type slug catchers are basically large diameter pipes designed to buffer two-phase flow slugs from offshore platforms and from pig/sphering operations into steady liquid flow thereby preventing potential overload of the gas/liquid handling capacity of the plant. Hydrocarbon gas is dehydrated at the offshore platform and transported with liquid hydrocarbons to the onshore slug catchers via the $24^{\prime \prime}$ inlet pipeline. The liquids formed in the pipeline should be removed in the slug catchers when $30 \%$ full and then piped to a metering system. There are currently removed when 60-80\% full with increased potential for solid deposition. The gas is subsequently filtered to remove any dirt/debris/remaining droplets prior to being piped to the gas treating facilities (i.e. separator) via a $24^{\prime \prime}$ gas header. The process flow is illustrated in Fig. 1.

\section{Results}

Inspection

External non-intrusive inspection (NII) techniques were used to detect and map internal corrosion in the slug catcher fingers. Internal corrosion (between the 4 and 8 o'clock positions) was detected in the fingers and glycol sump to levels which required immediate attention. Corrosion was found to be severe within the lower $15 \mathrm{~m}$ of the fingers, the condensate header and the glycol sump. Finger 2 was found to have a greater wide spread issue with corrosion throughout the length of the finger, however, the most severe corrosion was confined to the lower $15 \mathrm{~m}$. For areas where NII could not be carried out, intrusive inspection was required which was also used to validate the external findings. The intrusive campaign revealed large build-ups of deposits within the slug catcher and the formation of internal scales adhered to the internal surfaces. Associated with the most severe deposit build-up areas in the lower end (South) of the slug catcher was associated internal corrosion. An example is shown below of scale adhesion and internal corrosion (Fig. 2). A summary of the internal inspection findings and corresponding integrity of the slug catcher is given in Table 1.

There are potential reductions in the effectiveness of magnetic flux leakage (MFL) inspection in the region of the welds due to sensor lift-off. In the region of the weld, the standard detection threshold of $10 \%$ of wall thickness is 


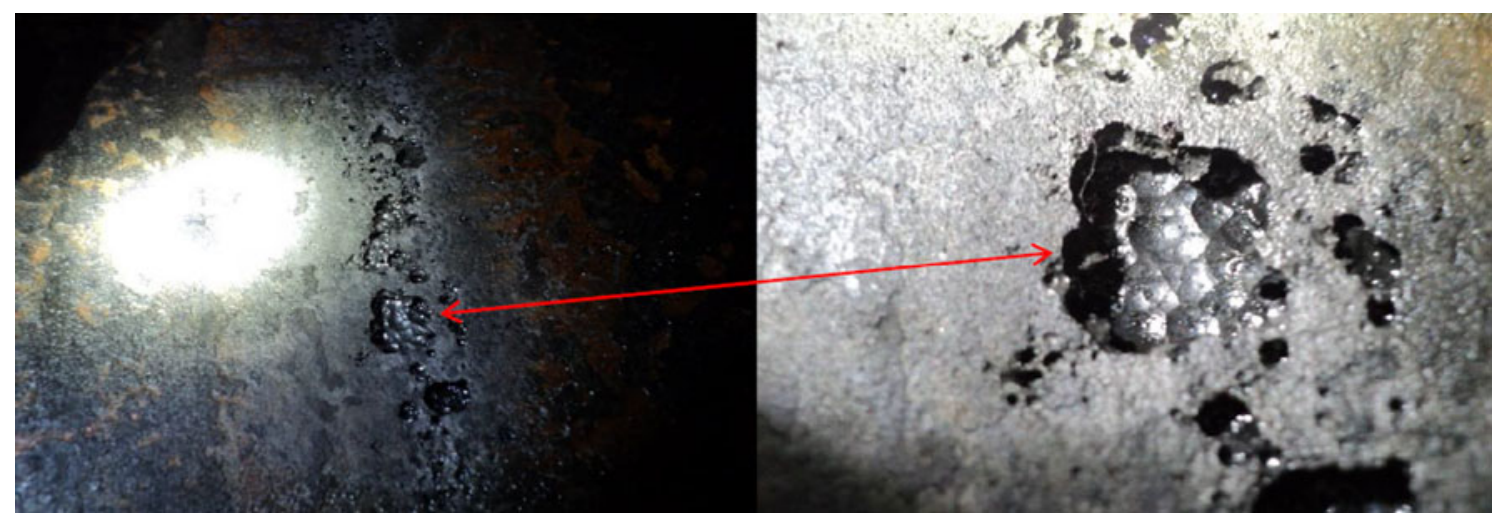

Fig. 2 Scale adhesion to internal surfaces of slug catcher-associated with areas of deposit build-up

Table 1 Summary of integrity status for design conditions

\begin{tabular}{lcccc}
\hline Component & $\begin{array}{c}\text { Required minimum thickness, } \\
\text { mm-design conditions }\end{array}$ & $\begin{array}{c}\text { Required minimum thickness, mm-design } \\
\text { conditions }\end{array}$ & $\begin{array}{c}\text { Minimum measured } \\
\text { thickness, mm }\end{array}$ & $\begin{array}{c}\text { Fit for service? Assuming } \\
\text { corrosion will continue }\end{array}$ \\
\hline $\begin{array}{l}\text { Fingers } \\
\begin{array}{l}\text { Condensate } \\
\text { header }\end{array}\end{array}$ & 20.3 & 18.8 & 17.8 & No \\
$\begin{array}{l}\text { Glycol } \\
\text { sump }\end{array}$ & 25.7 & No data & 25.2 & Yes \\
\hline
\end{tabular}

raised by $10 \%$, i.e. the tool will reliably detect defects in the welds that have depths that are greater than $20 \mathrm{wt} \%$. The defect depths seen in the slug catcher (up to $6 \mathrm{~mm}$ ) would typically correspond to approximately $15-30 \%$ of wall thickness in the pipeline. The depth sizing accuracy also reduces at the weld and it is feasible that deeper defects in the weld could be misreported or unreported. However, the reliability of detection and sizing increases with increasing defect dimensions and it would seem highly likely that PWC of the configuration seen in the slug catcher would give a strong MFL signal and would be detected by the MFL ILI tool if occurring in the pipeline.

For the inlet pipeline, the ILI data reported 65 girth weld anomalies in the inlet pipeline. These defects appear to be distributed randomly around the pipe circumference. There is no strong indication of orientation towards the bottom of the pipeline, as would be expected for PWC. This concurs with the view that these are fabrication defects. Based on these results, PWC is not considered to be prevalent in the inlet pipeline. This is attributed to the regular pigging/ sphering of the inlet pipeline compared with the slug catcher which is not piggable and hence full of deposits.

\section{Corrosion Rates, Sampling and Monitoring}

The $\mathrm{CO}_{2}$ concentration of the gas flowing through the inlet pipeline from the offshore platforms, range from 2.3 to
2.9 mol\% with an operating pressure of 1050 psi. The $\mathrm{CO}_{2}$ partial pressure (1.67 to 2.83 bara) is therefore classified as being in the medium likelihood of sweet corrosion. Corrosion rate increases with $\mathrm{CO}_{2}$ partial pressure (for scalefree $\mathrm{CO}_{2}$ corrosion) attributed to increased concentration of $\mathrm{HCO}^{-}$which accelerates the cathodic reaction. It is evident from the degradation morphology of the preferential weld corrosion (i.e. corrosion pits at the weld roots and HAZ) that $\mathrm{CO}_{2}$ corrosion was one of the mechanisms which contributed to the observed damage in the slug catcher. This would be expected given the historical lack of effective mitigation prior to recent implementation of the corrosion management strategy (CMS).

Corrosion pits were first observed in the slug catcher in 2005 following in-line inspection. The average corrosion rate determined that year by a corrosion prediction model was $0.46 \mathrm{~mm} /$ year. Corrosion rates subsequently increased every year to $0.71 \mathrm{~mm} /$ year in 2007 and then decreased to $0.41 \mathrm{~mm} /$ year in 2008. The decreased corrosion rate in 2008 can be explained by the increased MEG injection into the inlet pipeline. The main inhibitive effect of MEG on corrosion is thought to come from dilution of the water phase, which leads to a decreased activity of water.

The annual sampling results from 2005 to 2013 is shown in Fig. 3. Figure 4 shows the off-target monthly sampling results for the months prior to implementation of the CMS (i.e. May to Sept 2012). Fluid analyses (Fig. 3) indicate that residual 


\section{pH vs time}

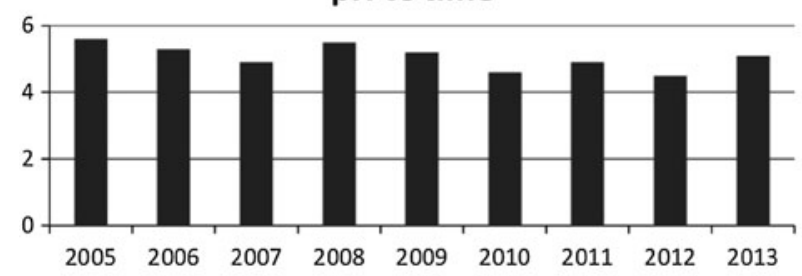

Chloride content (ppm) vs time

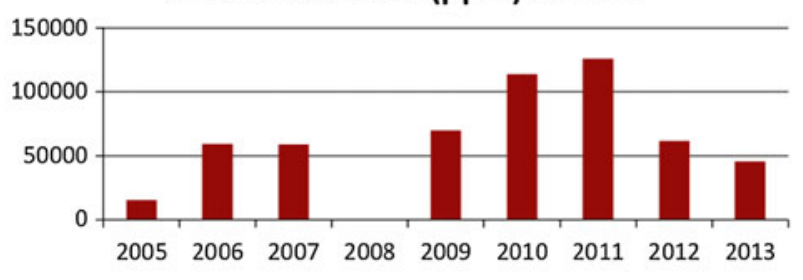

$\%$ Water vs time

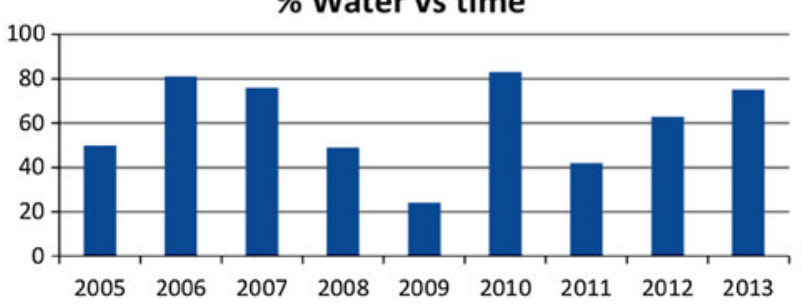

Fig. 3 Yearly fluid analyses 2005-2013

pH vs time

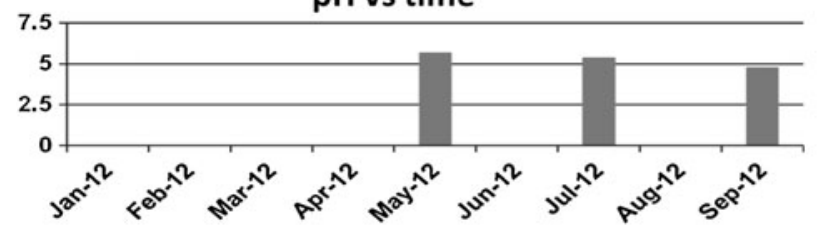

Chloride content (ppm) vs time

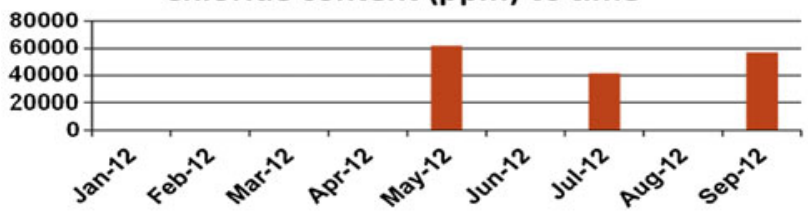

$\%$ Water vs time

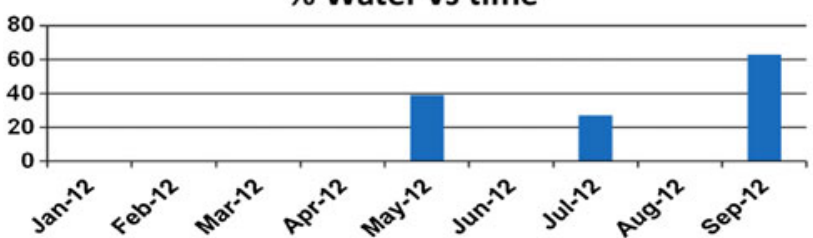

Iron count (ppm) vs time

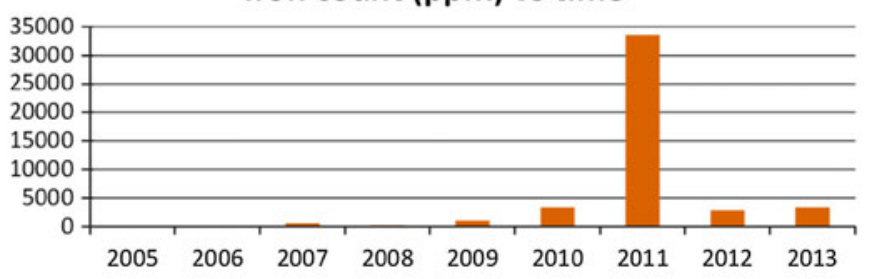

Corrosion Inhibitor (ppm) vs time

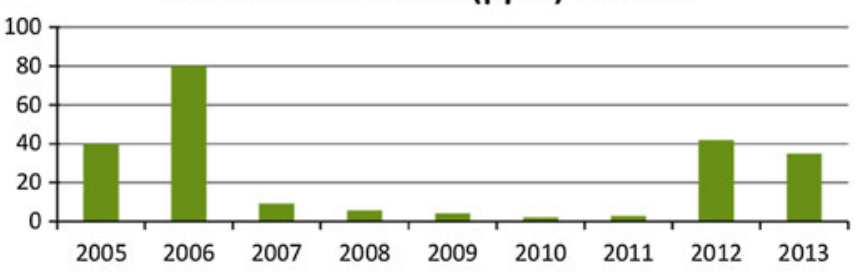

\% MEG vs time

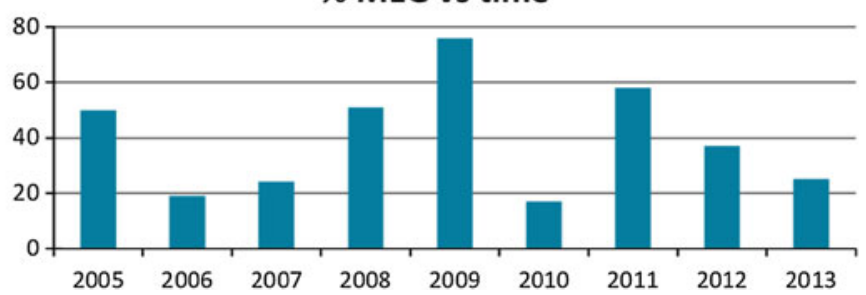




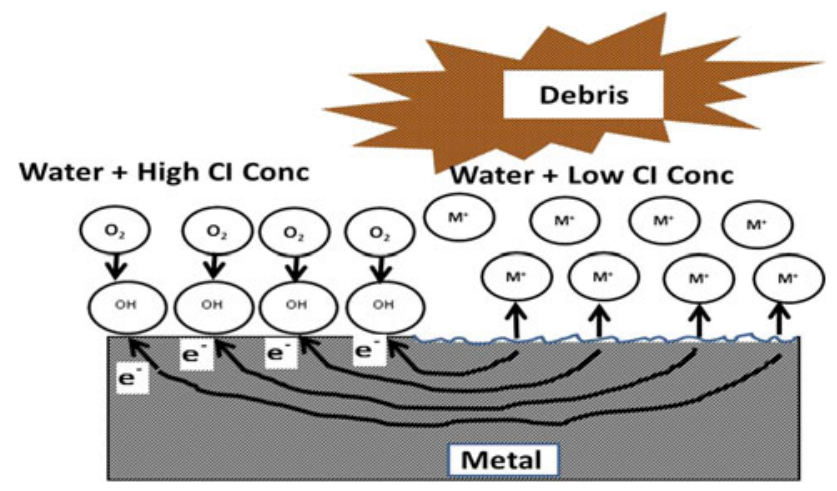

Fig. 5 Illustration of metal ion concentration mechanism under slug catcher debris

corrosion inhibitor ranged from $<5$ to $10 \mathrm{ppm}$ in 2007 through 2011 (target 100 ppm). During the same period, the glycol concentration ranged from ca. 15 to ca. $75 \%$ which suggests a water content between 25 and $85 \%$ (target $<5 \%$ ). Hence, in effect the slug catcher was exposed to uninhibited wet gas and free water for at least 5 years (Fig. 3).

The presence of organic acid radicals is also strongly indicated by the low $\mathrm{pH}$ of the lean MEG from the reboiler. Organic acids lower $\mathrm{pH}$ and consequently results in increased corrosion rate. The pH profile from 2005 to 2013 is shown in Fig. 3.

Corrosion pits were also observed under the debris in the slug catcher. The debris and also corrosion deposits are attributed to the pig sphering and also to the sweeping effects of the high gas flow rate in the pipeline and the subsequent flow rate reduction in the slug catcher. During intelligent pigging in 2009, the ILI tool became stuck due to hydrates in the pipeline and this was mitigated by injection of a large amount of MEG (see spike in Fig. 3). Full ILI run of the pipeline was carried out in 2011 which would have increased corrosion deposits collected from the pipeline into the slug catcher which would explain the large iron content spike in 2011 (Fig. 3). This spike was also contributed by a high water cut and low glycol concentration (high glycol water content) in 2010, The iron spike may indicate increased corrosion in 2011 due to a combination of these factors, or (more likely) corrosion products from upstream being swept into the slug catcher due to increased flow rates and the full ILI run. The high chlorides in 2010 and 2011 (Fig. 3) would have resulted in increased conductivity and corrosivity of the fluids.

Planktonic SRB counts show $<100$ cells/ml. However, a sessile bacteria colony which in this case is impractical to sample, can proliferate inside undercut pits and intensify pitting attack. Therefore, the contribution of MIC to the observed damage cannot be conclusively determined on the basis of the planktonic results.

The corrosion damaged areas which were exposed following the clean-out in October 2012 may have been re- deposited with fresh fluids, sludge and deposits carried through from the offshore pipelines consequently reducing the corrosion rate to more acceptable levels. Also since January 2013 the corrosion inhibitor injection skid has started to work effectively.

\section{Corrosion Mechanisms}

The key management priority was to identify the likely corrosion mechanism(s) that has occurred in the slug catcher and secondary separator and then develop and implement a corrosion control plan in order to reduce the corrosion rate from a recorded high of $0.71 \mathrm{~mm} /$ year in 2007 to a level required to achieve an extended life of another 20 years, i.e. $<0.125 \mathrm{~mm} /$ year.

\section{Metal Ion Concentration Cell Corrosion}

This is the primary type of corrosion under the debris observed in the slug catcher. The slug catcher metal area which is immersed in the less concentrated corrosion inhibitor solution (i.e. the anode, under the deposit) will corrode in preference to the cathodic areas immersed in the more concentrated corrosion inhibitor solution (i.e. the cathode). This mechanism is a typical example of metal ion concentration cell corrosion (Fig. 5) and though UDC is usually a synergy of different corrosion mechanisms, this is evidently a primary failure mechanism for the damage observed in this slug catcher.

The step-by-step process for the mechanism is described generically as follows (note that $\mathrm{M}^{+}$in this case represents $\left.\mathrm{Fe}^{2+}\right)$ :

1. Metal ions $\left(\mathrm{M}^{+}\right)$go into solution as a result of the difference in potential of the electrically connected slug catcher metal which is immersed in solutions having different concentrations of corrosion inhibitor (i.e. under and outside the deposit).

2. The metal ion $\left(\mathbf{M}^{+}\right)$concentration increases and saturates under the deposit resulting in the creation of a net positive charge in the crevice electrolyte.

3. Negatively charged ions dissolved in the crevice water are consequently attracted, i.e.

$\mathrm{M}^{+}+\mathrm{Cl}^{-} \rightarrow \mathrm{M}^{+} \mathrm{Cl}^{-}$

4. Thus chloride, sulphate and other anions present spontaneously concentrate in the crevice.

5. Hydrolysis (i.e. addition of water molecules) produces acids in the crevice thereby accelerating attack, i.e.

$$
\begin{aligned}
& \mathrm{M}+\mathrm{Cl}^{-}+\mathrm{H}_{2} \mathrm{O} \rightarrow \mathrm{MOH} \downarrow+\mathrm{H}^{+} \mathrm{Cl}^{-} \\
& \mathrm{M}_{2}^{+} \mathrm{SO}_{4}^{2-}+2 \mathrm{H}_{2} \mathrm{O} \rightarrow 2 \mathrm{MOH} \downarrow+\mathrm{H}_{2}^{+} \mathrm{SO}_{4}^{2-}
\end{aligned}
$$


6. This causes a significant reduction of the crevice $\mathrm{pH}$, typically to 2 or less even in production fluids having a neutral $\mathrm{pH}$. For sea water-contaminated produced water fluids (as was the case here) crevice $\mathrm{pH}$ may fall below 1 and the chloride concentration can be many times greater than in the bulk water.

7. The crevice environment becomes increasingly corrosive as acidic anions concentrate within. Recorded results also indicate the presence of organic acid radicals (carried through the low $\mathrm{pH}$ Lean MEG from the reboiler) which would have further contributed to the lowering of $\mathrm{pH}$ within the crevices, acidic conditions and increased corrosion rates.

8. Areas immediately adjacent to the crevice receive correspondingly increasing numbers of electrons from the crevice.

9. Hydroxyl ion formation increases just outside the crevice thereby locally increasing $\mathrm{pH}$ and decreasing attack there.

10. Corrosion inside the crevice becomes more severe with time due to spontaneous concentration of acidic anion.

The permeability of the debris controls the extent of replenishment of the anionic species under the deposit.

The results of a test by NPL [2] confirm that the rate of under deposit corrosion will be driven by the magnitude of the differential concentration of corrosion inhibitor in the bulk fluid and under the solid deposit. For the test, no inhibitor was injected initially before sand deposition, i.e. no inhibitor was present beneath the sand. When inhibitor was subsequently, injected into fluid, results showed that the average galvanic corrosion rate of the electrodes placed under sand reduced to an acceptable level $(0.1 \mathrm{~mm} / \mathrm{year})$ within 12 days. However, a number of electrodes continued to show unacceptably high corrosion rates of up to $1.6 \mathrm{~mm} /$ year. A second test which more adequately represented field conditions was carried out with 15 ppm inhibitor injected before introduction of sand and then followed by increased inhibitor injection (30 ppm) into the bulk fluid, as would happen when there is loss of pigging capability or in this case inability to effect timely water drainage from the slug catcher. Results showed that galvanic corrosion commenced and increased to a peak value of $0.27 \mathrm{~mm} /$ year (compare with $1.6 \mathrm{~mm} /$ year obtained when there was no inhibitor under the sand). This test was carried out at $30{ }^{\circ} \mathrm{C}$ and had $\mathrm{CO}_{2}$ constantly bubbled through the solution.

A similar result was reported in the paper by Tan et al. [3]. In their experiment, they measured the galvanic currents showing maps of corrosion potential distributions from a wire beam electrode (WBE) that was partially covered by sand. Under deposit corrosion did not occur during the exposure of the WBE to carbon dioxide saturated brine under ambient temperature. However introduction of corrosion inhibitor imidazoline and oxygen into the brine was found to significantly affect the patterns and rates of corrosion, leading to the initiation of under deposit corrosion over the WBE. Biomorgi et al. [4] developed a monitoring device which was deployed in situ to study the mechanism of under deposit corrosion in a real hydrocarbons pipeline. The result of their study which involved microscopic analyses show that pitting is related to the presence of sand and solids (iron carbonates and sulphides).

In summary when corrosion inhibitor is increased following failure of timely drainage of liquid from the slug catcher (and hence increased solid deposition) there is a corresponding increase of the rate of under deposit corrosion, i.e. the magnitude to the difference in CI concentrations above and under the deposit is proportional to the rate of UDC rate. When corrosion damage was first discovered in 2005, CI injections were significantly increased during 2006 (Fig. 3) in order to provide mitigation. This would have inadvertently resulted in increased corrosion rates under the deposit as discussed. The very low corrosion inhibitor injections over the next 5 years (Fig. 3) would have reduced the corrosion rate under the deposit but increased the corrosion rates on the metal surfaces with reduced inhibition, i.e. outside the deposits.

On the basis of these test results, reduction of corrosion inhibitor levels in the bulk fluid is recommended once high fluid corrosivity is indicated during significant solid deposition (e.g. if liquid is being consistently drained at $80 \%$ full rather than the threshold $30 \%$ over a long period of time). This should lower the differential concentration of corrosion inhibitor and consequently the rate of under deposit corrosion. However, it should be noted that this effect is only achieved if there is adequate corrosion inhibitor dosing prior to solid deposition. The extent of the reduction of $\mathrm{CI}$ should be determined by the responsible corrosion engineer.

\section{$\mathrm{CO}_{2}$ Corrosion}

The slug catcher receives wet gas at $\mathrm{CO}_{2}$ partial pressures of 1.67-2.03 bara. In low flow conditions (0.3 mm/year), $\mathrm{CO}_{2}$ dissolves in the water phase, increasing acidity and corrosivity and resulting in a high probability of pitting damage. While $\mathrm{pH}$ of the bulk solution is 6 and above, inside the crevices it can be lower than 2 thereby increasing corrosion rate. When $\mathrm{pH}$ is 4 or below, corrosion rate increases as a result of direct reduction of $\mathrm{H}^{+}$ions. $\mathrm{pH}$ stabilisation or buffering is therefore recommended as a means of reducing the corrosion rate to acceptable levels. However, it should be noted that there can be excessive scaling when this technique is used with formation (produced) waters. At higher $\mathrm{pH}$ (6 and above) general 


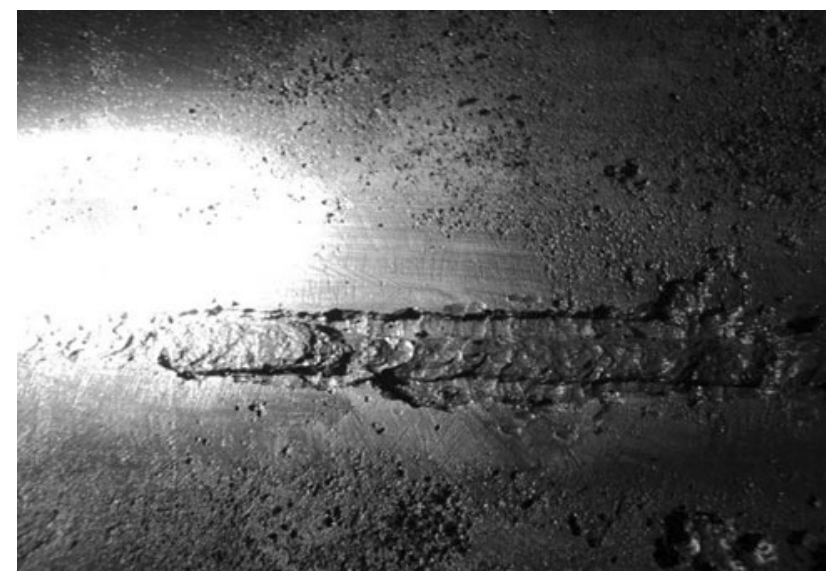

Fig. 6 Internal corrosion to slug catcher weld root and HAZ

corrosion rates stagnate or even decreases due to favourable conditions for maintenance of protective scaling which may increase susceptibility to pitting. The damage morphology in Fig. 2 shows the presence of adhered scales which may be attributed to precipitation of a thick, porous and detached film of iron carbonate, strongly favoured at the predicted $\mathrm{pH}$ of the bulk solution (5.8-6.8). This is further validated by the results of a corrosion loop experiment by Sun et al. [5], which showed that when $\mathrm{pH}$ is greater than 6 , a thick and porous film is formed on the bottom, which is typically detached from the metal surface and is likely to be responsible for the initiation of localised corrosion.

$\mathrm{CO}_{2}$ corrosion for this system should be monitored by continuous corrosion inhibitor injection, monitoring process parameters such as temperature, pressure and dew point, UT thickness checks, corrosion probes/coupons and intelligent pigging.

\section{Preferential Weld Corrosion}

PWC is caused by microstructural and/or compositional differences between the weld and its parent metal resulting in a galvanic effect. Produced water containing dissolved $\mathrm{CO}_{2}$ and high acetic acid increases the corrosivity of the fluid and hence the corrosion rate. Though nickel additions into the weld filler materials may make the weld less anodic, it may result in preferential corrosion of the HAZ [6]. Resistance to PWC increases with increased uniformity of microstructure and composition between the weld and HAZ/parent metal [7]. For this slug catcher, the composition of the weld filler materials were not available so it is unknown if they were of a composition designed to avoid PWC in the weld. The original pipelay welding would not have included post-weld heat treatment so the microstructure of the weld and HAZ could be such that preferential weld corrosion is feasible. Therefore it is assumed that $\mathrm{PWC}$ in the pipeline is feasible.

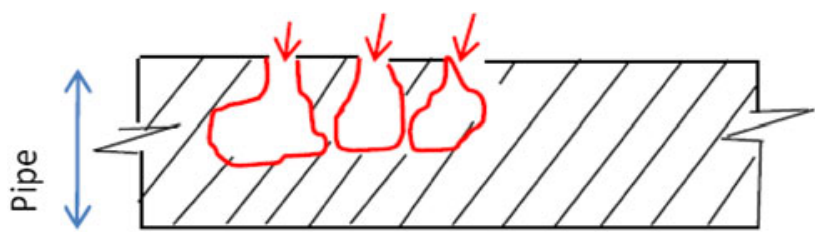

Fig. 7 Schematic of cavernous pitting observed in weld and parent metal

These compositional differences will create different corrosion potentials resulting in metal ions $\left(\mathrm{M}^{+}\right)$initially going into solution from the anodic areas and contributing to the corrosion reactions as explained in section 'Metal Ion Concentration Cell Corrosion'. The role of PWC mechanism under similar conditions was positively confirmed during the NPL test (ref) by electrodes being placed under the sand deposits at the parent metal (X65), weld and the affected zones respectively in order to check the effect of microstructure. Results showed that galvanic corrosion rates were significantly lower for the weld material than for the parent and HAZ material. Figure 6 shows the observed morphology of the attack.

Preferential weld corrosion should be monitored by UT thickness checks and online monitoring using welded probes.

\section{Microbial-Induced Corrosion}

The observed damage (Fig. 7) shows sharp undercut/cavernous pits which is a typical morphology of MIC damage. Bacterial colonies are more likely to form in low flow conditions, in localised areas such as welds and crevices under favourable conditions.

However, the result of the planktonic bacteria counts does not provide conclusive proof of MIC contributing to the observed damage. It is important to determine whether bacterial control/biocide injections will be required during future operations to assure integrity of this asset. Assessment of the likelihood of MIC (SRB) will require evaluation of its mechanism especially accounting for all the factors critical for SRB metabolism. Please note that acid producing bacteria (APB) is dependent on oxygen content and therefore discounted from consideration since the oxygen content of the gas is assumed to be low at the relatively high operating pressures (1050 psi). SRB cannot occur if any of these five factors is absent.

- Energy - corrosion must be present to provide energy (electron) to drive SRB metabolism. PWC and metal ion concentration cells are the pre-existing corrosion mechanisms.

- Water-must be present to initiate and take active part in the corrosion process. Water is present from the 


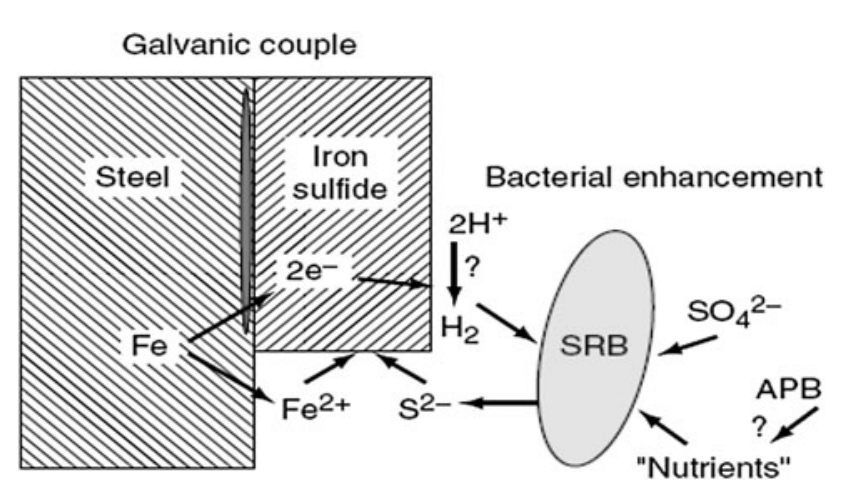

Fig. 8 Schematic of SRB mechanism in $\mathrm{FeS}$ (or $\mathrm{FeCO}_{3}$ ) corrosion cell

produced water-contaminated gas and condensate throughput.

- Sulphate-water present must contain sufficient levels of soluble sulphate for MIC to be credible. SRB's use cathodic hydrogen to reduce soluble sulphate to sulphide which is corrosive to the pipeline metal. The sulphate content of the produced water (not sampled) is assumed to come from injected sea water.

- Nutrient-SRB's require nutrient in the water to provide essential building materials (carbon, nitrogen, $\mathrm{P}$, etc.) for cell growth. For this hydrocarbon asset, the nutrient can be provided by biodegradation of hydrocarbons (gas and condensate).

- Temperature-MIC is credible in the temperature range of $20-70{ }^{\circ} \mathrm{C}$. The operating temperature of this slug catcher is approximately $30^{\circ} \mathrm{C}$. SRB's can remain in bacteriostatic mode below $20{ }^{\circ} \mathrm{C}$.

It is evident from this assessment that all the factors necessary for SRB activity were present. It can then be concluded that there was a high likelihood of SRB activity in the pits/crevices under the slug catcher deposit. Though the $\mathrm{H}_{2} \mathrm{~S}$ content of the gas downstream of the slug catcher is reported at a max of $1 \mathrm{ppm}$, downstream $\mathrm{H}_{2} \mathrm{~S}$ levels were not being monitored hence it was not possible to provide absolute confirmation of any observed increase resulting from SRB activity. In practice this is achieved by adequate biociding when offline and operationally by implementing a planned programme of operational cleanliness (routine sphering of inlet pipeline for finger-type slug catcher or jet washing for vessel-type sand/debris).

The SRB mechanism is illustrated in Fig. 8 and also summarised as follows:

1. Corrosion at anode involving loss of electrons

$\mathrm{Fe} \rightarrow \mathrm{Fe}^{2+}+2$ electrons

2. Dissociation of water into $\mathrm{H}^{+}$proton

$\mathrm{H}_{2} \mathrm{O} \leftrightarrow \mathrm{H}^{+}+\mathrm{OH}^{-}$
3. Electrons from anode reduce $\mathrm{H}^{+}$at metal surface to form cathodic hydrogen

$\mathrm{H}^{+}+2$ electrons $\rightarrow 2 \mathrm{H}$

4. Atomic (cathodic) hydrogen $\mathrm{H}$, escapes cathodic surface by any or combinations of these modes:

- Combines to form molecular hydrogen $\mathrm{H}_{2}$, desorbs and is lost to the bulk solution.

- Enters the metal matrix as atomic H.

- SRB use cathodic hydrogen to reduce soluble sulphate to sulphide (cathodic depolarisation)

$$
\mathrm{SO}_{4}^{2-}+8 \mathrm{H} \rightarrow \mathrm{S}^{2-}+\mathrm{H}_{2} \mathrm{O}
$$

5. The corrosion product is formed by combination of the reduced iron (in 1) with the sulphide anion (in 4)

$$
\mathrm{Fe}^{2+}+\mathrm{S}^{2-} \rightarrow \mathrm{FeS}
$$

Microbial-induced corrosion should be monitored by microbial sampling (sessile and planktonic), biostuds and UT thickness checks.

\section{Corrosion Control and Mitigation}

\section{Corrosion Control}

The immediate integrity plan for this asset includes UT wall thickness check of damaged areas followed by a corrosion management and control plan which is outlined in Table 2 (see KPI acceptance criteria for CCM in Table 3). Results should then be reviewed initially monthly by the corrosion/integrity/operations team to ensure that pitting is not progressing and that the corrosion rate remains below $0.125 \mathrm{~mm} /$ year as determined by the FFS assessments. Frequency may be increased subsequently to quarterly or as deemed necessary. Figure 9 shows the first set of sampling results after implementation of the corrosion management strategy. The results indicate compliance with the thresholds shown in Table 2.

Other areas which will play a part in the corrosion control strategy are:

- Having in place a pipeline pig cleaning programme which should be implemented in order to remove free water and debris/deposit. A 6-monthly frequency is recommended in order to prevent excessive build-up of deposit in the slug catcher.

- Sampling fluids from the pipelines at the pig receiver and check for: (a) salt content of MEG, (b) $\mathrm{pH}$, (c) corrosion inhibitor residual and full analysis of deposit including checks for anaerobic and aerobic presence. Monthly sampling is recommended. 


\section{pH vs time}

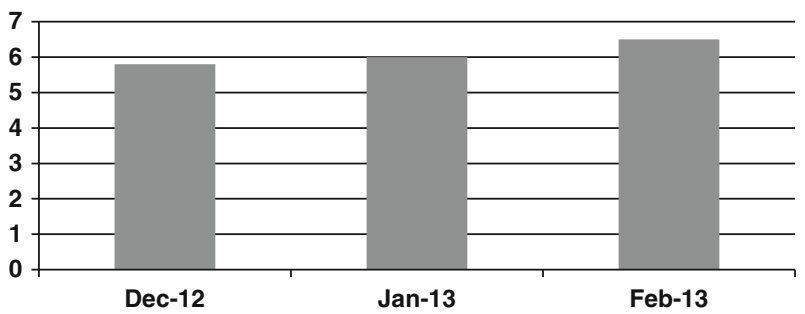

Dec-12

Jan-13

Feb-13

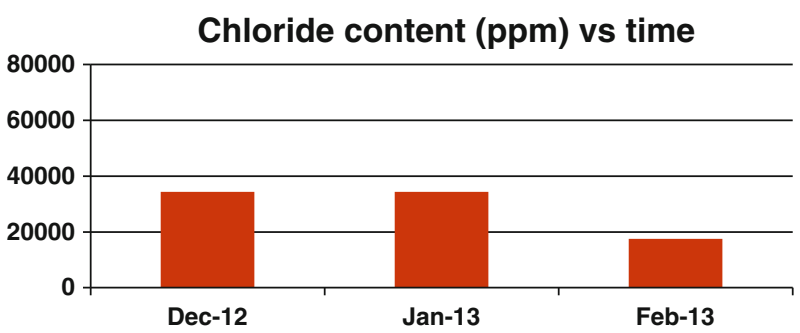

$\%$ Water vs time

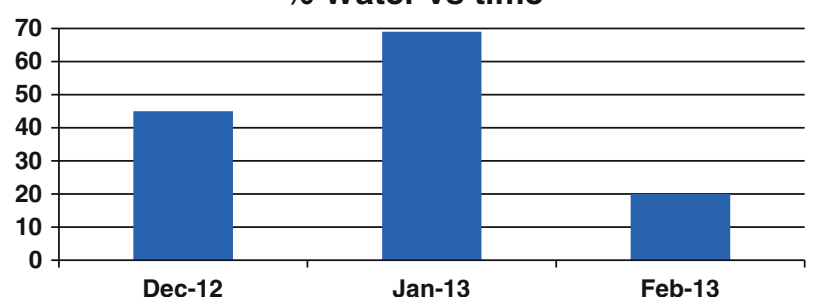

Iron count (ppm) vs time

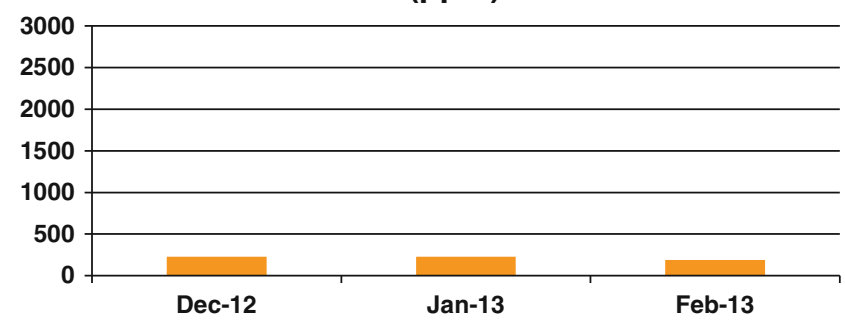

Corrosion Inhibitor (ppm) vs time

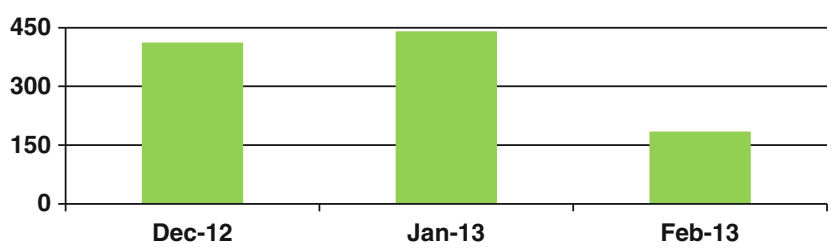

$\%$ MEG vs time

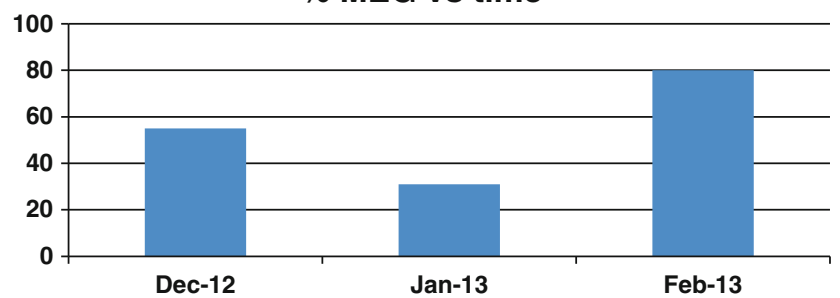

Fig. 9 Fluid analyses results Dec 2012 to Feb 2013-after implementation of the CMS

- Sampling of fluids within the slug catcher at the lowest point to monitor sessile/planktonic bacterial colonies and/or installation of bio probes at appropriate locations to get best value of the readings.

- Adjust $\mathrm{pH}$ of fluids upstream of slug catcher by injection of MEA and measure sample fluid $\mathrm{pH}$ at south end of slug catcher to make sure that the MEA is working.

- Biocide dosing which is currently carried out quarterly, at a ratio of 1:4 with the corrosion inhibitor.

- Review results and control plan on a 2-monthly basis (team to be corrosion/integrity/operations) to ensure that the corrosion plan is followed and strategy adjusted accordingly.

- Ultrasonic monitoring at damaged areas of slug catcher on a recommended frequency of 3 monthly. This frequency should be reviewed as required.

- Monitor the level of salt in the rich MEG and if within 40-50 g/l, discard the batch and make up the volume with new MEG, until the salt level is brought down to a lower level.

- Ensure that firing up of the fire tube is as efficient as is operationally practicable in order to achieve a better temperature distribution in the fire tube.
- Monitor salt level and manage pH of lean MEG at 9, by adding sufficient amounts of MEA/DEA.

Finger Versus Vessel-Type Slug Catcher

If periodic review of inspection and monitoring results by the corrosion and integrity team indicate that the target corrosion rate of $<0.125 \mathrm{~mm} /$ year is not being achieved, then the long term plan of replacing the finger-type slug catcher with a vessel-type should be considered for implementation.

Finger-type slug catcher designs consist of several long pieces of pipe (Fig. 10), which presents a very large surface area for solid deposition. Several operators have found this design to be too full of deposits for operation at the design rates and have consequently changed their designs from finger-type to vessel-type. Vessel-type slug catchers have inbuilt sand jetting systems for jetting high-pressure water through the length of the vessel and are thus able to deal with a wide range of deposition rates thereby minimising corrosion damage. Vessel-type designs (Fig. 11) have proven to be very reliable in service, easy to inspect and maintain and to give good separation of water, condensate and gas phases. 
Table 2 Corrosion management strategy for the slug catcher

\begin{tabular}{|c|c|c|c|c|c|}
\hline $\begin{array}{l}\text { Responsible } \\
\text { person }\end{array}$ & Activity & Location & Frequency & Threshold & Corrective actions \\
\hline $\begin{array}{l}\text { Process } \\
\text { engineer }\end{array}$ & $\begin{array}{l}\text { Monitor pipeline water } \\
\text { cut and check } \\
\text { volume }\end{array}$ & Slug catcher & $\begin{array}{l}\text { Monthly/every } \\
\text { sphere run }\end{array}$ & $7.0<\mathrm{pH}<9.0$ & $\begin{array}{l}\text { Sample, record } \mathrm{pH} \text { and if lower add } \mathrm{pH} \\
\text { enhancers such as MEA/DEA. Notify } \\
\text { Corrosion/Integrity Group }\end{array}$ \\
\hline $\begin{array}{l}\text { Process } \\
\text { engineer }\end{array}$ & $\begin{array}{l}\text { Monitor chloride (salt) } \\
\text { content within MEG }\end{array}$ & Slug catcher & $\begin{array}{l}\text { Monthly/every } \\
\text { sphere run }\end{array}$ & $<10,000 \mathrm{ppm}$ & $\begin{array}{l}\text { Sample and record chloride content. If } \\
\text { higher add pH enhancers such as } \\
\text { MEA/DEA and use fresh MEG. } \\
\text { Notify Corrosion/Integrity Group }\end{array}$ \\
\hline $\begin{array}{l}\text { Process } \\
\text { engineer }\end{array}$ & $\begin{array}{l}\text { Monitor pipeline fluid } \\
\text { residual corrosion } \\
\text { inhibitor }\end{array}$ & Slug catcher & $\begin{array}{l}\text { Monthly/every } \\
\text { sphere run }\end{array}$ & $>100$ ppm (in total fluids) & $\begin{array}{l}\text { Sample and record the CI residual and if } \\
\text { lower increase continuous dosage } \\
\text { rate. Notify Corrosion/Integrity } \\
\text { Group }\end{array}$ \\
\hline $\begin{array}{l}\text { Ops } \\
\text { engineer }\end{array}$ & $\begin{array}{l}\text { Monitor water content } \\
\text { of pipeline fluid } \\
\text { residual rich glycol }\end{array}$ & Slug catcher & $\begin{array}{l}\text { Monthly/every } \\
\text { sphere run }\end{array}$ & $<20$ vol. $\%$ water & $\begin{array}{l}\text { Sample and record water content. } \\
\text { Notify corrosion/integrity group }\end{array}$ \\
\hline $\begin{array}{l}\text { Process } \\
\text { engineer }\end{array}$ & $\begin{array}{l}\text { Monitor iron count in } \\
\text { the pipeline fluid }\end{array}$ & Slug catcher & Monthly & $<50 \mathrm{ppm}$ & $\begin{array}{l}\text { Sample and record iron content. Notify } \\
\text { Corrosion/Integrity Group }\end{array}$ \\
\hline $\begin{array}{l}\text { Ops } \\
\text { engineer }\end{array}$ & $\begin{array}{l}\text { Bacterial monitoring } \\
\text { (sessile/planktonic } \\
\text { from low point fluid } \\
\text { analyses or bio } \\
\text { probes) }\end{array}$ & Slug catcher & $\begin{array}{l}\text { Monthly/every } \\
\text { sphere run } \\
\text { when } \\
\text { sampling is } \\
\text { carried out }\end{array}$ & $\begin{array}{l}\text { Presence of sulphate- } \\
\text { reducing bacteria (SRB)/ } \\
\text { general heterotrophic } \\
\text { bacteria (GHB) activity } \\
<100 / \mathrm{ml}\end{array}$ & $\begin{array}{l}\text { Weekly sampling done (every sphere } \\
\text { run bringing the fluids to the slug } \\
\text { catcher) and send to lab and forward } \\
\text { results to Corrosion/Integrity Group }\end{array}$ \\
\hline $\begin{array}{l}\text { Ops } \\
\text { engineer }\end{array}$ & $\begin{array}{l}\text { Monitor water content } \\
\text { of lean glycol before } \\
\text { transferred to } \\
\text { offshore platforms }\end{array}$ & $\begin{array}{l}\text { Glycol/MEG } \\
\text { skids }\end{array}$ & $\begin{array}{l}\text { Before every } \\
\text { tanker load } \\
\text { is dispatched } \\
\text { offshore }\end{array}$ & $<0.5$ vol. $\%$ water & $\begin{array}{l}\text { Confirm correct operating conditions of } \\
\text { glycol skid/reboiler. Record results, if } \\
\text { higher, drain; refill and use fresh } \\
\text { MEG. Notify Corrosion/Integrity } \\
\text { Group }\end{array}$ \\
\hline $\begin{array}{l}\text { Process } \\
\text { engineer }\end{array}$ & $\begin{array}{l}\text { Monitor pH of lean } \\
\text { glycol before it is } \\
\text { transferred to the } \\
\text { offshore platforms }\end{array}$ & $\begin{array}{l}\text { Glycol/MEG } \\
\text { skids }\end{array}$ & $\begin{array}{l}\text { Before every } \\
\text { tanker load } \\
\text { is dispatched } \\
\text { offshore }\end{array}$ & $7.0<\mathrm{pH}<9.0$ & $\begin{array}{l}\text { Add } \mathrm{pH} \text { enhancers such as MEA/DEA } \\
\text { to glycol/MEG skid (tank) before it is } \\
\text { dispatched offshore. Record results } \\
\text { and notify the Corrosion/Integrity } \\
\text { Group }\end{array}$ \\
\hline $\begin{array}{l}\text { Process } \\
\text { engineer }\end{array}$ & Biocide dosing regime & $\begin{array}{l}\text { Injection point } \\
\text { of biocide at } \\
\text { upstream of } \\
\text { slug catcher }\end{array}$ & $\begin{array}{l}\text { Biocide } \\
\text { injection } \\
\text { along with } \\
\text { MEG every } \\
4 \text { weeks }\end{array}$ & $\begin{array}{l}800 \text { ppm of the total fluids } \\
\text { entering the slug catcher } \\
\text { which is equivalent to } \\
\sim 161 \text { of biocide }\end{array}$ & $\begin{array}{l}\text { Record biocide qty injected, residuals } \\
\text { sampled and check with threshold } \\
\text { and notify Corrosion/Integrity Group }\end{array}$ \\
\hline
\end{tabular}

\section{General Conclusions and Recommendations}

This system (classified as being in the medium likelihood of sweet corrosion) received little or no corrosion inhibitor injection during a 5-year period. Corrosion management activities were also being partially implemented during this period. Organic acid in the entrant pipeline fluid was strongly indicated due to entrant glycol decomposition products associated with upset conditions at the reboiler.

Routine inspection detected internal corrosion (between the 4 and 8 o'clock positions) in the slug catcher fingers and glycol sump. The observed damage was found to be associated with the areas of severe deposit build-up, mostly in the lower sections. Prior to detection of damage, liquid drainage was occurring when the slug catcher was $80 \%$ full instead of the recommended $30 \%$ thereby increasing the amount of deposit.

Results of API579 fitness for service assessments of the corroded areas justified the subsequent decision to de-rate the system and that no further corrosion can be tolerated at the original design pressure, at least until the rates of corrosion and its mechanisms are fully understood.

The observed damage morphology suggests a synergy of the following primary mechanisms: under deposit corrosion, $\mathrm{CO}_{2}$ corrosion, preferential weld corrosion and microbial-induced corrosion.

Implementation of the following inspection and corrosion control activities have been recommended in order to reduce corrosion rate from a predicted high of $0.71 \mathrm{~mm} /$ 
Table 3 KPI acceptance criteria (corrosion control matrices)

\begin{tabular}{|c|c|}
\hline \multicolumn{2}{|c|}{ Corrosion inhibition (continuous) } \\
\hline \multicolumn{2}{|c|}{ Proportion of time injected } \\
\hline Green & $>90 \%$ \\
\hline Amber & $80-89 \%$ \\
\hline Red & $<80 \%$ \\
\hline \multicolumn{2}{|c|}{ Injection rate } \\
\hline Green & $90-120 \%$ of required rate \\
\hline Amber & $50-89 \%$ of required rate \\
\hline Red & $<50 \%$ of required rate \\
\hline \multicolumn{2}{|c|}{ Reclaimed MEG } \\
\hline \multicolumn{2}{|l|}{$\mathrm{pH}$} \\
\hline Green & $\mathrm{pH}>7$ \\
\hline Amber & pH 6-7 \\
\hline Red & $\mathrm{pH}<6$ \\
\hline \multicolumn{2}{|l|}{ Chlorides } \\
\hline Green & $<10,000 \mathrm{ppm}$ \\
\hline Amber & $10,000-12,000 \mathrm{ppm}$ \\
\hline Red & $>12,000 \mathrm{ppm}$ \\
\hline \multicolumn{2}{|c|}{ Water content } \\
\hline Green & $26 \%$ \\
\hline Amber & $>26<35 \%$ \\
\hline Red & $>35 \%$ \\
\hline \multicolumn{2}{|c|}{ Sampling of fluids } \\
\hline \multicolumn{2}{|c|}{ Samples taken as scheduled? } \\
\hline Green & Within $110 \%$ of allowed time period \\
\hline Amber & $111-150 \%$ of allowed time period \\
\hline Red & $>150 \%$ of allowed time period \\
\hline \multicolumn{2}{|c|}{ Testing of samples carried out } \\
\hline Green & All tests performed \\
\hline Amber & $50-100 \%$ performed \\
\hline Red & $<50 \%$ tests performed \\
\hline \multicolumn{2}{|c|}{ Corrosion monitoring } \\
\hline \multicolumn{2}{|c|}{ Corrosion coupons retrieved } \\
\hline Green & Within $150 \%$ of allowed time period \\
\hline Amber & $151-200 \%$ of allowed time period \\
\hline Red & $>200 \%$ of allowed time period \\
\hline \multicolumn{2}{|c|}{ Corrosion coupons measured } \\
\hline Green & Yes \\
\hline Amber & Samples unsuitable \\
\hline Red & No measurement \\
\hline \multicolumn{2}{|c|}{ Sphering/pigging } \\
\hline \multicolumn{2}{|c|}{ Sphering undertaken? } \\
\hline Green & Within $150 \%$ of allowed time period \\
\hline Amber & $151-200 \%$ of allowed time period \\
\hline Red & $>200 \%$ of allowed time period \\
\hline \multicolumn{2}{|c|}{ V-jet pigging undertaken? } \\
\hline Green & Within $150 \%$ of allowed time period \\
\hline Amber & $151-200 \%$ of allowed time period \\
\hline Red & $>200 \%$ of allowed time period \\
\hline
\end{tabular}

Table 3 continued

\begin{tabular}{ll}
\hline $\begin{array}{l}\text { Gas dehydration } \\
\text { Dewpoint }\end{array}$ & \\
Green & Within spec \\
Amber & Within $3{ }^{\circ} \mathrm{C}$ of spec \\
Red & Outside $3{ }^{\circ} \mathrm{C}$ of spec \\
In-line inspection (ILI) & \\
ILI time interval between inspections \\
Green & Within 1 year of allowed time interval \\
Amber & Between 1 and 2 years of time interval \\
Red & $>2$ years overdue \\
Completion of actions & \\
Green & All actions completed \\
Amber & $>50 \%$ planned actions completed \\
Red & $<50 \%$ planned actions completed
\end{tabular}

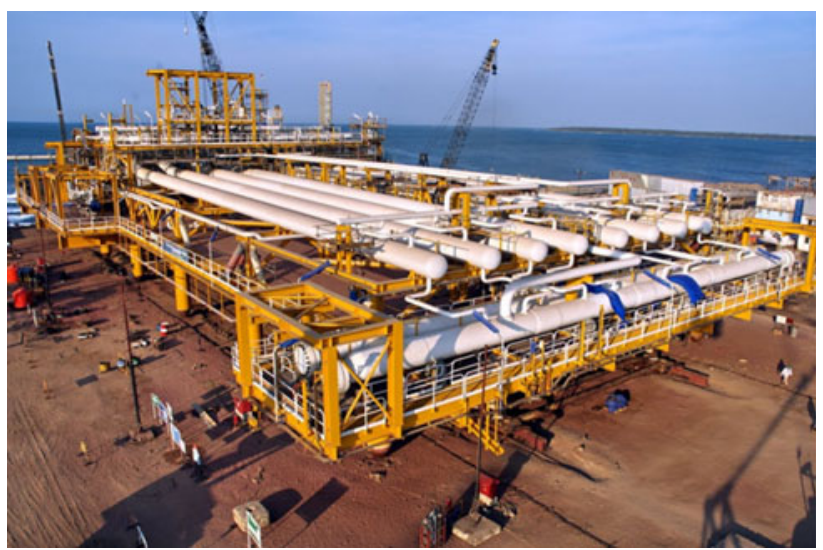

Fig. 10 Finger-type slug catcher-large surface area available for solid deposition, less inspectability and maintainability

year in 2007 to $0.125 \mathrm{~mm} /$ year due to these mechanisms and so achieve an extended life of another 20 years.

- Ultrasonic monitoring at damaged areas of slug catcher

- Pigging

- Sampling of fluids within the slug catcher for chloride, iron count, sessile/planktonic counts

- Monitor pipeline water cut

- Monitor corrosion inhibitor and biocide residuals

- Corrosion monitoring devices: corrosion coupons, online monitoring and bio studs

- Addition of MEA/DEA to adjust $\mathrm{pH}$ above 6 when required

- Batch biocide dosing and continuous corrosion inhibitor injection

- Sampling salt and water levels of glycol and management of pH of lean MEG by adding sufficient amounts of MEA/DEA 


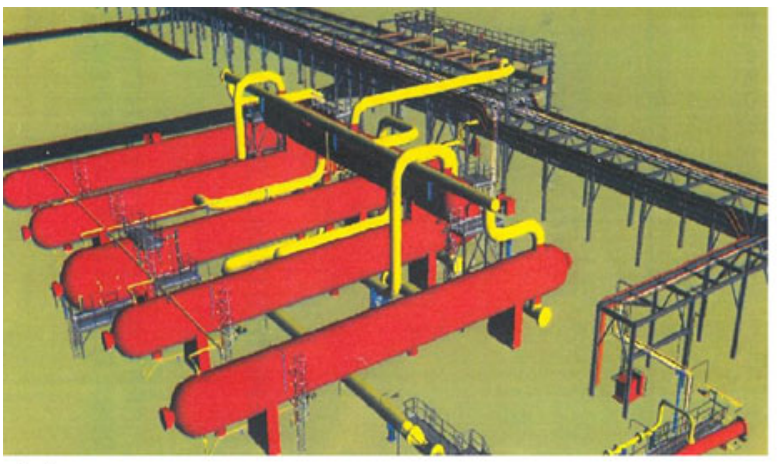

(a)

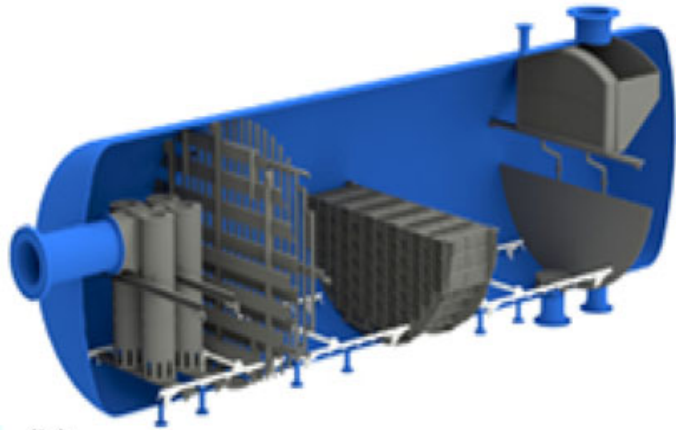

(b)

Fig. 11 (a) 3D model of vessel-type slug catcher-easily inspectable and maintainable. (b) Cut-out section showing the 'sand jetting' or 'sand flushing' system used to remove solid deposits

- Efficient firing up of reboiler in order to achieve a better temperature distribution

Results of these activities should be reviewed by the corrosion/integrity/operations team initially monthly and subsequently quarterly as may be required. If the outcome of this review suggest that the corrosion rate is not being controlled within the required limit, i.e. $<0.125 \mathrm{~mm}$ as determined by FFS assessments, then the repair or replace options should be considered. If the replacement option is selected, the vessel-type slug catcher is preferred over the finger-type since the latter is equipped with sand jetting systems for removal of solids and which will translate to less susceptibility to associated corrosion.

Open Access This article is distributed under the terms of the Creative Commons Attribution License which permits any use, distribution, and reproduction in any medium, provided the original author(s) and the source are credited.

\section{References}

1. API/ASME Standard API 579-1/ASME FFS-1, Fitness-for Service

2. Evaluation of Inhibitor Performance Using NPL Underdeposit Corrosion Test (X65 Carbon Steel), NPL Test Report, p. 2, 11th May 2011, Teddington

3. Y. Tan, Y. Fwu, K. Bhardwaj, Electrochemical evaluation of under-deposit corrosion and its inhibition using the wire beam electrode method. Corros. Sci. 53(4), 1254-1261 (2011)

4. J. Biomorgi, S. Hernandez, J. Marin, E. Rodriguez, M. Lara, A. Viloria, Internal corrosion studies in hydrocarbons production pipelines located at Venezuelan Northeastern. Chem. Eng. Res. Des. 90(9), 1159-1167 (2012)

5. Y. Sun, K. George, S. Nesic, The effect of Cl- and acetic acid on localized $\mathrm{CO}_{2}$ corrosion in wet gas flow. Paper presented at Corrosion 2003, Institute for Corrosion and Multiphase Technology Ohio University, Athens, $\mathrm{OH}$

6. Guidance for Corrosion Management in Oil and Gas production and Processing, The Energy Institute, London, May 2008

7. C. Lee, S. Bond, P. Woollin, Preferential weld corrosion: effects of weldment microstructure and composition. Paper presented at NACE 2005 Houston, Texas, 3-7 April 2005 